\title{
Synergism between the Lewis and Brönsted acid sites on HZSM-5 zeolites in the conversion of methylcyclohexane
}

\author{
Chenhai Song a, Meng Wang a, Li Zhao a, Nianhua Xue a,*, Luming Peng a Xuefeng Guo a, \\ Weiping Ding a,\#, Weimin Yang ${ }^{b}$, Zaiku Xie ${ }^{b}$ \\ a Key Laboratory of Mesoscopic Chemistry of MOE, School of Chemistry and Chemical Engineering, Nanjing University, Nanjing 210093, Jiangsu, China \\ ${ }^{\mathrm{b}}$ Shanghai Research Institute of Petrochemical Technology, SINOPEC, Shanghai 201208, China
}

\section{A R T I C L E I N F O}

Article history:

Received 27 September 2013

Accepted 8 October 2013

Published 20 November 2013

\section{Keywords:}

Methylcyclohexane

HZSM-5

Steam treatment

Synergistic effect

Lewis acid site

Brönsted acid site

\begin{abstract}
A B S T R A C T
Catalytic conversion of methylcyclohexane was studied on four specially designed HZSM-5 zeolites. A careful steam treatment was used to produce pair-sites composed of a Lewis acid site, due to extra-framework Al species from the dealumination by steaming, and a Brönsted acid site, due to bridging hydroxyl in the steamed HZSM-5. The spatial proximity of these component acid sites of the pair-site was verified by ${ }^{1} \mathrm{H}$ double quantum magic spinning NMR. Product selectivities of methylcyclohexane conversion showed the same trend for all the samples, which indicated that the pores of the zeolites were not changed by the steam treatment. The Lewis acid site that was created, however, gave a synergistic effect with the Brönsted acid site in the pair-site, which gave higher conversions and cracking rates of methylcyclohexane. The rate of methylcyclohexane conversion increased with increased concentration of extra-framework $\mathrm{Al}$, which gave more pair-sites.
\end{abstract}

(C) 2013, Dalian Institute of Chemical Physics, Chinese Academy of Sciences. Published by Elsevier B.V. All rights reserved.

\section{Introduction}

Dearomatization during catalytic cracking is an important topic, e.g. dearomatization of methycyclohexane (MCH), decalin, and tetralin is used to improve the cetane number of diesel fuel to give high quality liquid fuels for internal combustion engines with maximum combustion effectiveness and minimum emissions. On the other hand, with the rapid growth in the demand for ethene and especially propene, the ring opening and cracking of aromatics with condensed rings also offers a strategy to increase olefin production. $\mathrm{MCH}$ has been used as a model reactant to investigate ring opening reactions for many years over various acidic, and mono- and bimetallic catalysts [1-18]. Selective ring opening (SRO) towards target products is very important for producing either ethene and propene or other hydrocarbons for highly efficient combustion. The most effective SRO strategy to date is obtained with bifunctional catalysts of acids and metals [3,7,9,11,15-19]. The acidic sites catalyze dehydrogenation, cracking, isomerization, and dealkylation while the metal sites promote hydrogenation, hydrogenolysis, and isomerization. A balanced metallic-acidic bifunctional catalyst is necessary to achieve optimal performance [20]. Zeolites such as HMFI, HFAU, and HBEA are also often used as acidic catalysts or as supports of metals for ring opening reactions.

As acidic catalysts, zeolites are extremely active for the ring opening reaction because they cause the $\mathrm{MCH}$ molecule to be directly protonated to nonclassical carbonium ions with a

\footnotetext{
*Corresponding author. Tel: +86-25-83686115; Fax: +86-25-83317761; E-mail: nianhua@nju.edu.cn

\# Corresponding author. Tel: +86-25-83595077; Fax: +86-25-83317761; E-mail: dingwp@nju.edu.cn

This work was supported by the National Natural Science Foundation of China (21273107, 21103087), the Fundamental Research Funds for the Central Universities (1107020524), and the Specialized Research Fund for the Doctoral Program of Higher Education (20100091120035).

DOI: 10.1016/S1872-2067(12)60721-9 | http://www.sciencedirect.com/science/journal/18722067 | Chin. J. Catal., Vol. 34, No. 11, November 2013
} 
three-center, two electron bond in the transition state (Hagg-Dessau cracking) [3]. Because steam added into the reaction stream is beneficial for the elimination of coke deposits, the dealumination of zeolites by steaming has been investigated, and it has been found that steamed zeolites are more active for alkane conversion. The extra-framework Al (EFAl) species formed during steaming give Lewis acid sites (LAS), which were shown to always exist in close proximity to framework aluminum sites (Brönsted acid sites, BAS) in dealuminated HZSM-5 by ${ }^{1} \mathrm{H}$ and ${ }^{27} \mathrm{Al}$ double quantum magic angle spinning (DQ MAS) NMR spectroscopy [21].

The presence of synergism between the LAS and BAS that are in close proximity in steamed zeolites and its effect on $\mathrm{MCH}$ conversion and product distribution is an interesting subject. In the present work, a careful steam treatment was carried out on HZSM-5 zeolites with various Si/Al ratios (16-140) to produce pair-sites of LAS and BAS of different concentrations. These zeolites were used for MCH conversion at $703 \mathrm{~K}$ under strictly controlled conditions to keep MCH conversion to less than 5\%. Enhanced conversion and cracking rates of the MCH molecules were observed on the zeolites that have the pair sites of LAS and BAS. The synergy between the LAS and BAS was shown to give the enhanced reaction rate using correlations with the results of ${ }^{1} \mathrm{H}$ DQ MAS NMR experiments.

\section{Experimental}

\subsection{Materials}

The HZSM-5 zeolites were purchased from Zeolyst International and denoted as HZSM-5- $x$, where $x$ represented the $\mathrm{Si} / \mathrm{Al}$ ratio determined by ${ }^{29} \mathrm{Si}$ MAS NMR. The steamed HZSM- 5 zeolites were obtained by treating the fresh zeolites at $753 \mathrm{~K}$ with a water-argon mixture (water:Ar = 1:3, v:v) flow for $1 \mathrm{~h}$. The deionized water was injected into the system at a rate of 1.2 $\mathrm{ml} / \mathrm{h}$ with a SGE $25 \mathrm{MDF}-L \mathrm{~L}-\mathrm{GT}$ syringe on a LongerPump LSP 01-2A pump. The steamed zeolites were named as HZSM-5- $x$-S.

\subsection{Characterization}

X-ray diffraction (XRD) patterns of the samples were recorded in the $2 \theta$ region of $5^{\circ}-90^{\circ}$ on a Philips X'Pert X-ray diffractometer with $\mathrm{Cu} K_{\alpha}$ radiation $(40 \mathrm{kV}, 40 \mathrm{~mA}, \lambda=1.5418 \AA$ ). The scan speed was set at $15^{\circ} / \mathrm{min}$ with a step size of $0.017^{\circ}$. The specific surface areas and pore volumes of samples were measured by argon adsorption at $77 \mathrm{~K}$ using an automated gas adsorption analyzer (Micromeritics ASAP 2020). Samples were pretreated at $573 \mathrm{~K}$ under vacuum before the measurement. The total surface area was calculated using the BET method. The pore volume was evaluated with the $t$-plot method using the equation of Harkins and Jura.

${ }^{27} \mathrm{Al}$ and ${ }^{29} \mathrm{Si}$ MAS NMR experiments were performed on a Bruker Avance III spectrometer at resonance frequencies of 104.3 and 79.5 MHz, respectively. ${ }^{27} \mathrm{Al}$ MAS NMR spectra were recorded using a $4 \mathrm{~mm}$ MAS probe and a spinning rate of 14 $\mathrm{kHz}$ with a $\pi / 6$ pulse length of $1.4 \mu \mathrm{s}$ and a recycle delay of $0.1 \mathrm{~s}$ for all the hydrated samples. The chemical shift was referenced to $\mathrm{Al}\left(\mathrm{NO}_{3}\right)_{3}(0.1 \mathrm{~mol} / \mathrm{L})$ solution. ${ }^{29} \mathrm{Si}$ MAS NMR spectra were recorded using a $7 \mathrm{~mm}$ MAS probe with a $\pi / 2$ or $\pi / 8$ pulse length of $4.5 \mu \mathrm{s}$, a recycle delay ranging from 10 to $40 \mathrm{~s}$ at a spinning rate of $6 \mathrm{kHz}$. The chemical shift was referenced to 4,4-dimethyl-4-silapentane-1-sulfonic acid (DSS) at $1.534 \mathrm{ppm}$.

${ }^{1} \mathrm{H}$ DQ MAS NMR experiments were performed using a 3.2 $\mathrm{mm}$ probe with a spinning rate of $20 \mathrm{kHz}$. The zeolite sample was packed into a quartz tube and evacuated at $383 \mathrm{~K}$ for $7 \mathrm{~h}$, then heated to $673 \mathrm{~K}$ at a rate of $2 \mathrm{~K} / \mathrm{min}$ and maintained for 12 $\mathrm{h}$ at a pressure below $1 \times 10^{-5} \mathrm{~Pa}$ to remove adsorbed water in the zeolite. After the sample was cooled to room temperature, it was packed into a $3.2 \mathrm{~mm} \mathrm{ZrO}_{2}$ rotor in the glove box. The DQ coherences were excited and reconverted with the BABA (back to back) dipolar recoupling sequence [22].

\subsection{Catalytic test}

The HZSM-5 samples were tested for the conversion of MCH in a fixed bed system at $101 \mathrm{kPa}$. The zeolite sample was placed in a quartz U-tube reactor and heated to $803 \mathrm{~K}$ at a rate of 10 $\mathrm{K} / \mathrm{min}$ and then maintained at that temperature for $2 \mathrm{~h}$ under an argon flow of $120 \mathrm{ml} / \mathrm{min}$. Then the tube temperature was decreased to $703 \mathrm{~K}$, and liquid MCH was introduced to the system at a rate of $0.72 \mathrm{ml} / \mathrm{h}$ with a SGE 25MDF-LL-GT syringe and a LongerPump LSP 01-2A pump. The amounts of HZSM-5 zeolite used were from 10 to $50 \mathrm{mg}$. Reaction products were analyzed online by gas chromatography using an Agilent HP-AL/S capillary column and an Agilent HP-PONA capillary column and a flame ionization detector.

\section{Results and discussion}

X-ray powder patterns of the fresh and steamed zeolite crystals are shown in Fig. 1. All the samples were highly crystalline, and no significant change in crystallinity was observed after the steam treatment at $703 \mathrm{~K}$ for $1 \mathrm{~h}$. Table 1 shows the physico-chemical properties of the fresh and steamed zeolites. The surface areas were $341-383 \mathrm{~m}^{2} / \mathrm{g}$ for the four zeolites. The micropore volumes were similar and about $0.15 \mathrm{~cm}^{3} / \mathrm{g}$. Dynamic light scattering showed that the particle sizes of the HZSM-5 zeolites with the different $\mathrm{Si} / \mathrm{Al}$ ratios were almost the same and about $300 \mathrm{~nm}$. NMR measurements showed that the densities of the framework $\mathrm{Al}\left(\mathrm{Al}_{\mathrm{F}}\right)$ in these zeolites before steam treatment were in agreement with the $\mathrm{Si} / \mathrm{Al}$ ratios from the composition analysis. After the steam treatment, the densities of $\mathrm{Al}_{\mathrm{F}}$ in the zeolites were less due to loss from the zeolite framework by steaming at high temperatures, and there was more loss from the zeolite with a low $\mathrm{Si} / \mathrm{Al}$ ratio.

The ${ }^{27} \mathrm{Al}$ MAS NMR spectra of the HZSM-5 zeolites are shown in Fig. 2. The fresh HZSM-5 samples exhibited a dominant resonance at $54 \mathrm{ppm}$, which originated from tetrahedrally coordinated $\mathrm{Al}$. In addition to this, a weak resonance at $0 \mathrm{ppm}$ was also observed, which indicated the presence of octahedrally coordinated $\mathrm{Al}$ and which was assigned to the nonframework $\mathrm{Al}$ in the HZSM-5 zeolites. In summary, the ${ }^{27} \mathrm{Al},{ }^{29} \mathrm{Si}$ MAS NMR spectra (Fig. 3a) and XRF analysis of the fresh zeolites showed that the EFAl were $6.3 \%$ in HZSM-5-16, and $0.3 \%$, 

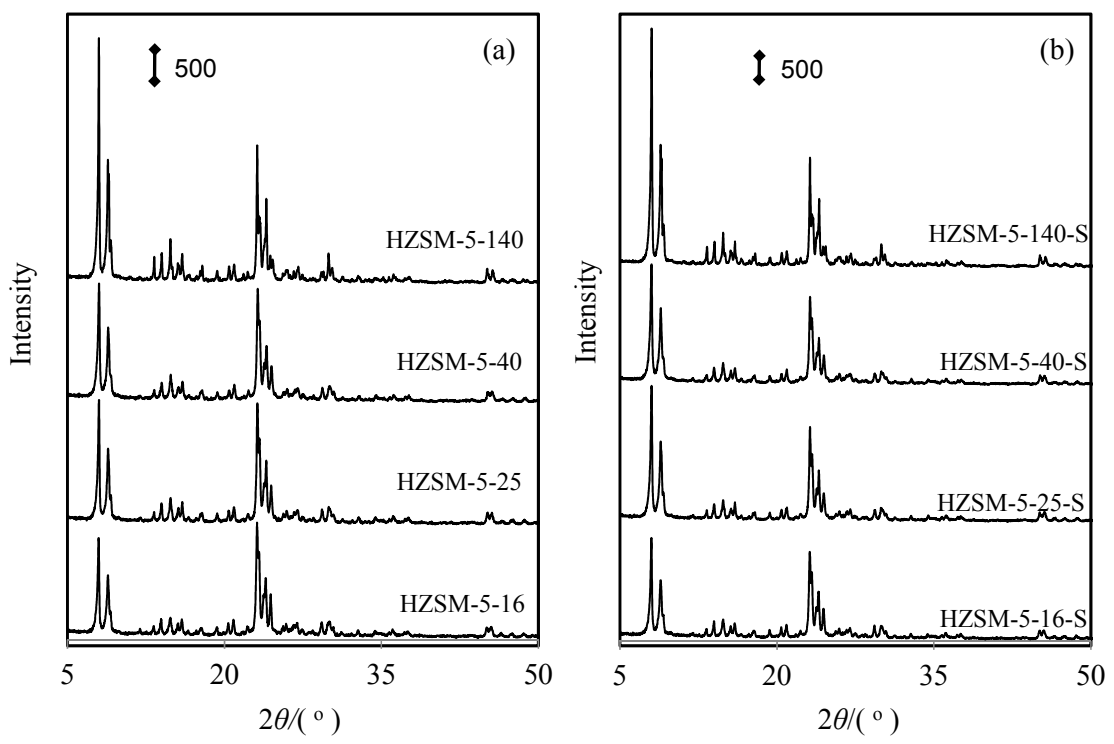

Fig. 1. XRD patterns of fresh (a) and steamed (b) HZSM-5 zeolites.

Table 1

Physico-chemical properties of the HZSM-5 zeolites.

\begin{tabular}{|c|c|c|c|c|c|}
\hline Catalyst & $\begin{array}{l}\mathrm{Al}_{\mathrm{F}} \text { density }{ }^{\mathrm{a}} \\
(\mu \mathrm{mol} / \mathrm{g})\end{array}$ & $\begin{array}{l}\mathrm{Al}_{\mathrm{F}} \text { density after steam } \\
\text { treatment }^{\mathrm{a}}(\mu \mathrm{mol} / \mathrm{g})\end{array}$ & $\begin{array}{l}\text { Micropore volume } \\
\left(\mathrm{cm}^{3} / \mathrm{g}\right)\end{array}$ & $\begin{array}{l}\text { Specific surface } \text { area }^{b} \\
\qquad\left(\mathrm{~m}^{2} / \mathrm{g}\right)\end{array}$ & $\begin{array}{l}\text { Particle size }{ }^{\mathrm{c}} \\
\text { (nm) }\end{array}$ \\
\hline H-ZSM-5-16 & 980 & 667 & 0.143 & 360 & 285 \\
\hline H-ZSM-5-25 & 641 & 476 & 0.150 & 351 & 317 \\
\hline H-ZSM-5-40 & 406 & 333 & 0.147 & 383 & 291 \\
\hline H-ZSM-5-140 & 118 & 87 & 0.147 & 341 & 328 \\
\hline
\end{tabular}

${ }^{a}$ Calculated by ${ }^{29} \mathrm{Si}$ MAS NMR. ${ }^{\mathrm{b}}$ Obtained from Argon adsorption at $77 \mathrm{~K} .{ }^{\mathrm{c}}$ Measured by dynamic light scattering.

0.7\%, and 1.4\% in HZSM-5-25, HZSM-5-40, and HZSM-5-140, respectively.

After the steam treatment, a more intense resonance at 0 ppm and a relatively broad resonance peak was observed from 20 to $40 \mathrm{ppm}$ in the ${ }^{27} \mathrm{Al}$ MAS NMR spectra of steamed zeolites (Fig. 2b), which was due to dealumination during the steam treatment. The broadening of the framework Al signal was due to the distortion of the tetrahedrally coordinated environment of the framework Al. From the XRF analysis and ${ }^{29} \mathrm{Si} \mathrm{MAS} \mathrm{NMR}$
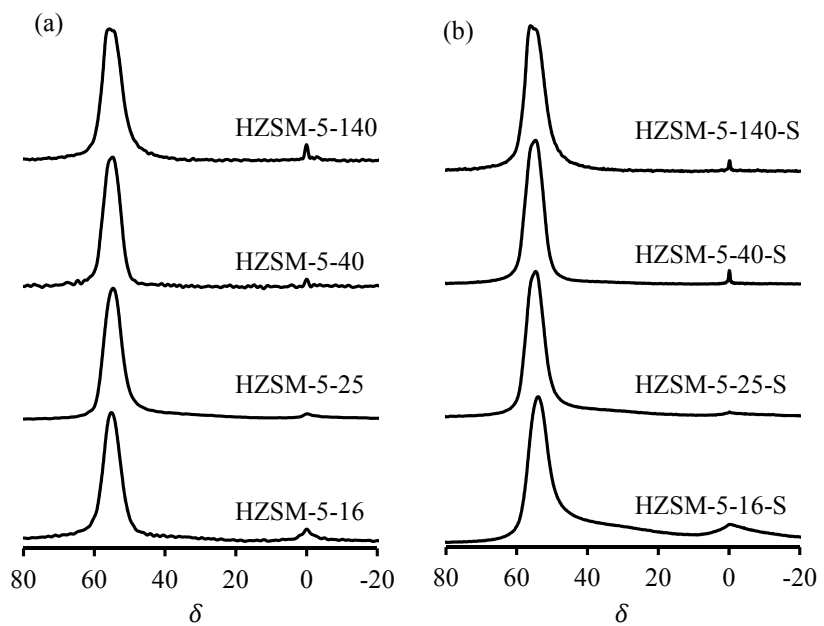

Fig. 2. Solid state ${ }^{27} \mathrm{Al}$ MAS NMR spectra of fresh (a) and steamed (b) HZSM-5 zeolites.
(Fig. 3b) spectra of the steamed zeolites, the $\mathrm{Al}_{\mathrm{F}}$ content was obtained and summarized in Table 1 . The steam treatment at $753 \mathrm{~K}$ for $1 \mathrm{~h}$ resulted in $32 \%, 26 \%, 20 \%$, and $27 \%$ of $\mathrm{Al}_{\mathrm{F}}$ being lost from the zeolitic framework of HZSM-5-16, HZSM-5-25, HZSM-5-40, and HZSM-5-140, respectively, which gave EFAl species with Lewis acidity.

The ${ }^{29}$ Si MAS NMR spectra of the HZSM- 5 zeolites are shown in Fig. 3. With the fresh and steamed HZSM-5 zeolites, the spectra exhibited a dominant resonance at $-113 \mathrm{ppm}$, which partly overlapped a resonance at $-115 \mathrm{ppm}$. These two resonances were assigned to $\mathrm{Si}(\mathrm{OSi})_{4}$ sites in the framework structure of the HZSM-5 zeolites [23]. A resonance at $-110 \mathrm{ppm}$ appeared in the spectra of HZSM-5-140 and HZSM-5-140-S zeolites, which was also assigned to $\mathrm{Si}(\mathrm{OSi})_{4}$ sites [23]. A broad resonance ranging from -100 to $-109 \mathrm{ppm}$ was also observed, which was from $\mathrm{AlOSi}(\mathrm{OSi})_{3}$ and $\mathrm{HOSi}^{*}(\mathrm{OSi})_{3}$. This was due to that each $\mathrm{OH}$ group and each $\mathrm{AlO}_{4}$ unit connected to the $\mathrm{SiO}_{4}$ tetrahedron decreased the ${ }^{29} \mathrm{Si}$ chemical shift by approximately 5 to 8 ppm. Similarly, a new resonance at -99 ppm was observed in the spectra of H-ZSM-5-16 and H-ZSM-5-16-S zeolites, which was also assigned to $\mathrm{AlOSi}^{*}(\mathrm{OSi})_{3}$ and $\mathrm{HOSi}^{*}(\mathrm{OSi})_{3}$ [24]. Based on the ${ }^{29} \mathrm{Si}$ MAS NMR results, the ratio of silicon to framework aluminum in the HZSM-5 zeolites was estimated using the equation [25] $(\mathrm{Si} / \mathrm{Al})_{\mathrm{NMR}}=I / \sum 0.25 n I_{n}$, where $I$ denotes the sum of the peak areas of the NMR signals assigned to the $\mathrm{Si}(n \mathrm{Al})$ building unit, and $I_{n}$ represents the intensity of the resonance corresponding to the $(\mathrm{AlO})_{n} \mathrm{Si}(\mathrm{OSi})_{4-n}$ sites. By com- 


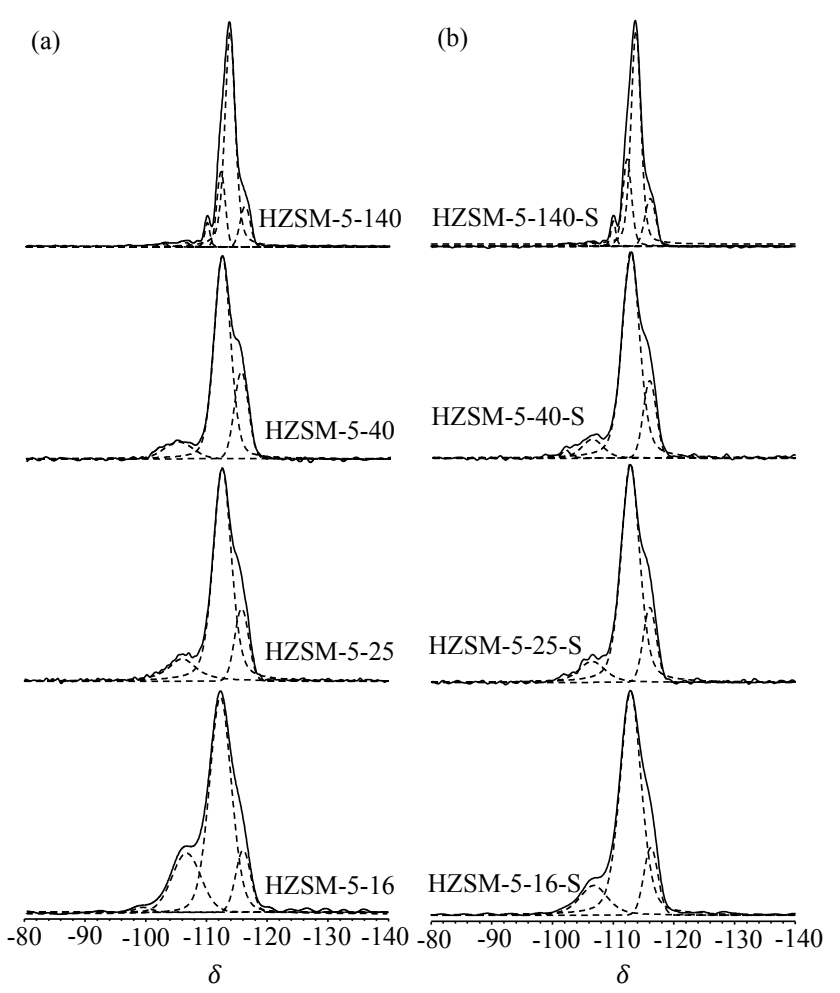

Fig. 3. Solid state ${ }^{29} \mathrm{Si}$ MAS NMR spectra of fresh (a) and steamed (b) HZSM-5 zeolites.

paring the $\mathrm{Si} / \mathrm{Al}$ ratios from the ${ }^{29} \mathrm{Si}$ MAS NMR results with that from the chemical analysis, which gave the bulk composition, the amount of extra-framework aluminium in the zeolites were calculated. The calculated results are shown in Table 1. The steam treatment reduced the NMR signal intensity of $\mathrm{AlOSi}^{*}(\mathrm{OSi})_{3}$ and increased the ratio of $\mathrm{Si}$ to $\mathrm{Al}_{\mathrm{F}}$ in the zeolites, which were consistent with the ${ }^{27} \mathrm{Al}$ MAS NMR data.

According to previous studies $[1,3,4,6,8,10,12,26]$, in the $\mathrm{MCH}$ reaction, $\mathrm{MCH}$ is first adsorbed at the active sites and the transition state (the molecule (TS) in Scheme 1) is cracked or dehydrogenated to alkenes, e.g. 1-methyl-1cyclohexene and $\mathrm{C}_{7}$ alkenes, through a carbonium ion mechanism. The consequent secondary cracking and dehydrogenation have a carbenium ion

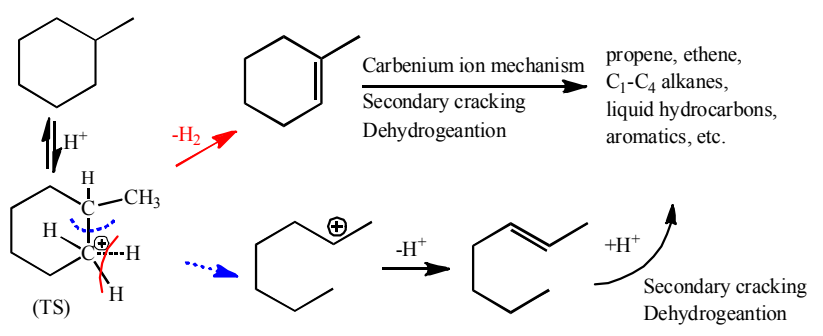

Scheme 1. Reaction network of MCH conversion over acidic zeolites.

chain mechanism. The products are complex and include $\mathrm{C}_{1}-\mathrm{C}_{7}$ alkanes and alkenes, benzene, toluene and minor $\mathrm{C}_{7+}$ hydrocarbons.

Figure 4 depicts the conversion and total cracking rate of MCH on the fresh and steamed HZSM-5 zeolites as a function of the density of the $\mathrm{Al}_{\mathrm{F}}$ in zeolite, which corresponded to the Brönsted acid sites. To determine the specific conversion rate per acid site, each of all the $\mathrm{Al}_{\mathrm{F}}$ atoms detected by ${ }^{29} \mathrm{Si} \mathrm{MAS}$ NMR were considered to form a Brönsted acid site in the zeolites. The conversion shown in Fig. 4a represents the number of methylcyclohexane molecules converted per acid site per second. The conversion of $\mathrm{MCH}$ increased with the $\mathrm{Al}_{\mathrm{F}}$ concentration over both fresh and steamed zeolites. A linear relationship was found between methylcyclohexane conversion and the square of the protonic acid site concentration, which suggested that this was a demanding reaction (two sites required for its catalysis) [27]. The result revealed that the different conversions were due to the different densities of Brönsted acid sites in the zeolite. When the density of Brönsted acid sites was low, the conversion of MCH was mainly on single active sites. When the density of Brönsted acid sites was high enough for the active sites to be adjacent to each other, "pair site" catalysis of MCH conversion was dominant. This explained the higher conversion over the zeolite with the higher density of Brönsted acid sites. The cracking reaction rate also showed a similar increase when the density of Brönsted acid sites was increased, as shown in Fig. $4 \mathrm{~b}$.

Over the steamed HZSM-5 zeolites, MCH conversion and the total cracking rate were both significantly and exponentially
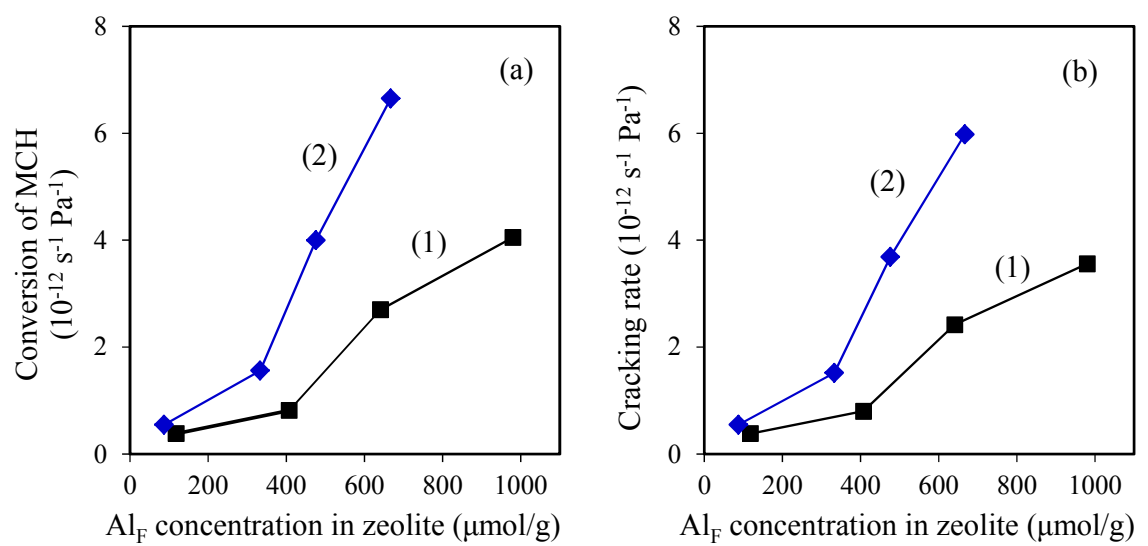

Fig. 4. Conversion (a) and cracking rate (b) of MCH over fresh (1) and steamed (2) HZSM-5 zeolites. Reaction conditions: Ar (120 ml/min) and MCH $(1.2 \mathrm{ml} / \mathrm{min}), 703 \mathrm{~K}, 130 \mathrm{~min}$ reaction. 
enhanced although the density of framework $\mathrm{Al}$ was reduced by the steam treatment. This phenomenon can be understood using the consideration that Lewis acidity originated from the EFAl in the HZSM-5. Extra-framework aluminum ions formed in zeolite pores by steam treatment have been revealed to modify the catalytic properties of the zeolite [30-35], including porosity modification, which alter the distribution of products $[28,29]$ and change of zeolitic acidity due to the formation of partially distorted octahedral aluminum atoms. [36-41]. It has been also reported that tri-coordinate $\mathrm{Al}_{\text {III }}$ sites formed in the HZSM-5 channels are responsible for the dissociation of methane at ambient temperatures, which was attributed to the formation of EFAl sites [42]. We believe that the significant increase in MCH conversion and cracking observed in the present work over the steamed zeolites was due to the existence of EFAl, which polarized or activated the MCH molecules. The synergistic interaction required proximity of the LAS and BAS in the channels. Lercher and co-workers [28] have reported that the mobility of the EFAl species gives access to BAS in the zeolite channels.

Figure 5 shows the ${ }^{1} \mathrm{H}$ DQ MAS NMR spectra of HZSM-5-40 and HZSM-5-40-S. The peaks that occur along the diagonal $(\omega$, $2 \omega$ ) are autocorrelation peaks resulting from the dipolar interaction of protons of the same chemical shift, while the pairs of off-diagonal peaks at $\left(\omega_{\mathrm{a}}, \omega_{\mathrm{a}}+\omega_{\mathrm{b}}\right)$ and $\left(\omega_{\mathrm{b}}, \omega_{\mathrm{a}}+\omega_{\mathrm{b}}\right)$ corresponded to correlations between two protons with different chemical shifts [43]. In the spectrum of HZSM-5-40 (Fig. 5a), an autocorrelation peak at $(2.2,4.4)$ indicated autocorrelation among the silanols. The off-diagonal peak pairs at $(4.3,7.0)$ and $(2.7,7.0)$ in Fig. $5 \mathrm{~b}$ confirmed the close spatial proximity between the $\mathrm{AlO}_{x}(\mathrm{OH})_{y}$ group (LAS) and the bridging OH group (BAS) in the steamed zeolite [44]. The results gave the amount of adjacent LAS and BAS in the steamed zeolites. Taken together, the DQ MAS NMR results and enhanced conversion and cracking rate in $\mathrm{MCH}$ conversion allowed the conclusion of a synergistic effect between adjacent LAS and BAS. The MCH molecule is adsorbed on a bridging $\mathrm{OH}$ site and forms the transition state with the carbonium ion. The adjacent LAS acts on the activated $\mathrm{MCH}$ molecule, and this polarization effect makes ring opening easier. The proposed activation process of the MCH molecule is presented in Scheme 2.

For all the fresh and steamed zeolites, methane, $\mathrm{C}_{2}, \mathrm{C}_{3}, \mathrm{C}_{4}$,

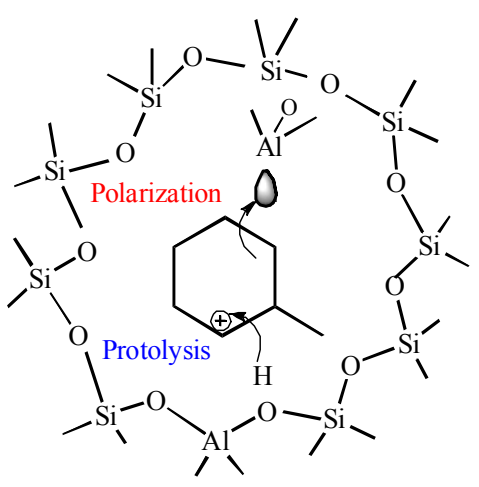

Scheme 2. Activation of methylcyclohexane by the synergistic effect between LAS and BAS.

and $\mathrm{C}_{7}$ olefinic products, isomers and toluene were the direct products of $\mathrm{MCH}$ conversion. $\mathrm{C}_{2}, \mathrm{C}_{3}, \mathrm{C}_{4}, \mathrm{C}_{5}, \mathrm{C}_{6}$, and $\mathrm{C}_{7}$ alkanes and other aromatics were secondary products [27]. Figure 6 shows the change of the selectivities of the products with $\mathrm{MCH}$ conversion. The results showed that propene, ethene, and butenes were the main cracking products. It is interesting that the steam treatment of the zeolites has almost no influence on the product distribution, indicating that the topology of the zeolite pores and channels, which governed product distributions in the MCH conversion, was not changed. The activity for MCH conversion was mainly controlled by the acidity of the catalyst [12]. The reaction of $\mathrm{MCH}$ conversion followed a Haag-Dessau cracking mechanism over the steamed HZSM-5 zeolites, but adjacent LAS and BAS pair-sites significantly promoted the reaction rate of $\mathrm{MCH}$.

\section{Conclusions}

A steam treatment under mild conditions resulted in the creation of Lewis acid sites (LAS) adjacent to Brönsted acid sites (BAS) in HZSM-5, which was due to dealumination during the steaming. The rapid increase in the conversion of methycyclohexane was due to a synergistic effect between the weak Lewis and strong Brönsted acid sites. ${ }^{1} \mathrm{H}$ DQ MAS NMR measurements also showed the synergy. The steamed HZSM-5 catalyst is a new catalyst system, which is a Haag-Dessau catalyst but with an additional polarization effect by adjacent LAS and
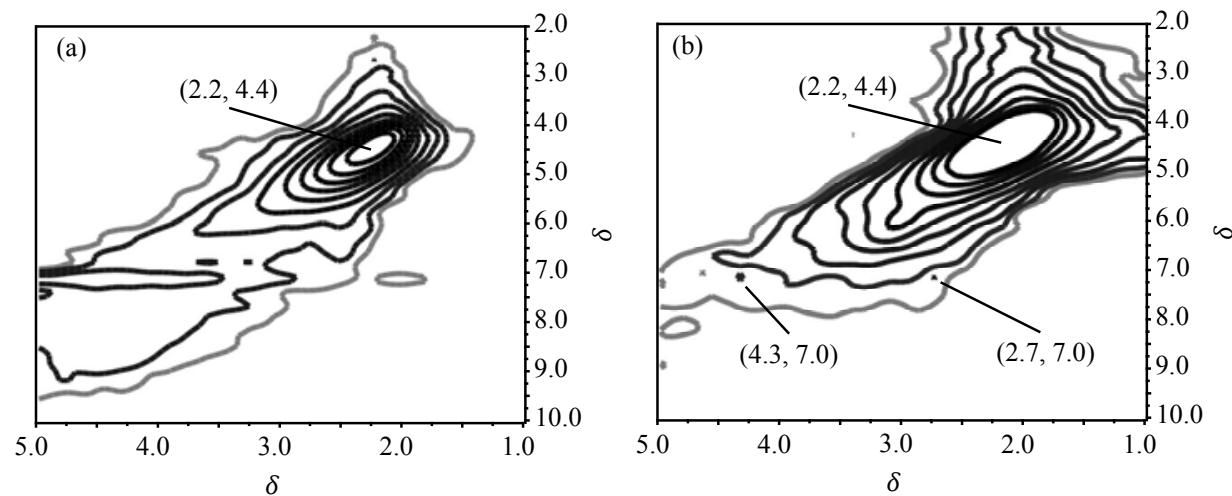

Fig. 5. Solid-state ${ }^{1}$ H DQ MAS NMR spectra of fresh (a) and steamed (b) HZSM-5-40 zeolites. 

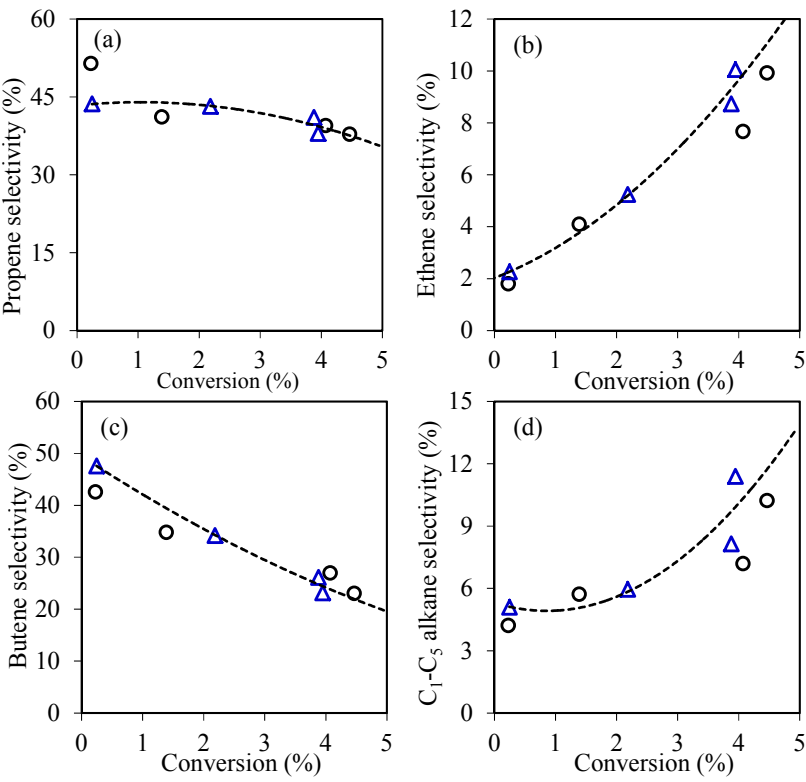

Fig. 6. Product selectivity of methylcyclohexane transforamtion over fresh (O) and steamed ( $\Delta$ ) HZSM-5 zeolites. (a) Propene; (b) Ethene; (c) Butenes; (d) $\mathrm{C}_{1}-\mathrm{C}_{5}$ alkanes. Reaction conditions: $\operatorname{Ar}(120 \mathrm{ml} / \mathrm{min})$ and $\mathrm{MCH}(1.2 \mathrm{ml} / \mathrm{min}), 703 \mathrm{~K}, 130 \mathrm{~min}$ reaction.

BAS pair-sites on the transition state of the methylcyclohexane reaction that helped its conversion.

\section{References}

[1] Corma A, Mocholi F, Orchilles V, Koermer G S, Madon R J. Appl Catal, 1990, 67: 307

[2] Mignard S, Caillette P, Marchal N. Chem Ind (Dekker), 1994, 58: 447

[3] Raichle A, Traa Y, Fuder F, Rupp M, Weitkamp J. Angew Chem Int Ed, 2001, 40: 1243

[4] Cerqueira H S, Mihindou-Koumba P C, Magnoux P, Guisnet M. Ind Eng Chem Res, 2001, 40: 1032
[5] Calemma V, Carati A, Flego C, Giardino R, Millini R. Prepr Symp Am Chem Soc, Div Fuel Chem, 2005, 50: 116

[6] Galperin L B, Jan D Y, McCall M J, Kocal J A, Galperin I, Uop LLC, USA. 2006, p 10 pp.

[7] Calemma V, Carati A, Flego C, Giardino R, Gagliardi F, Millini R, Bullussi G. ChemSusChem, 2008, 1: 548

[8] Castano P, Gayubo A G, Pawelec B, Fierro J L G, Arandes J M. Chem Eng J, 2008, 140: 287

[9] Lecarpentier S, van Gestel J, Thomas K, Gilson J P, Houalla M. J Catal, 2008, 254: 49

[10] Al-Sabawi M, de Lasa H. AIChE J, 2009, 55: 1538

[11] Park J W, Thomas K, van Gestel J, Gilson J P, Collet C, Dath J P, Houalla M. Appl Catal A, 2010, 388: 37

[12] Van Borm R, Reyniers M F, Martens J A, Marin G B. Ind Eng Chem Res, 2010, 49:10486

[13] Shi H, Gutierrez O Y, Haller G L, Mei D H, Rousseau R, Lercher J A. J Catal, 2013, 297: 70

[14] Moraes R, Thomas K, Thomas S, Van Donk S, Grasso G, Gilson J P, Houalla M. J Catal, 2013, 299: 30

[15] Upare D P, Yoon S, Lee C W. Catal Lett, 2012, 142: 744

[16] Moraes R, Thomas K, Thomas S, Van D S, Grasso G, Gilson J P, Houalla M. J Catal, 2012, 286: 62

[17] Nageswara Rao R, You N, Yoon S, Upare D P, Park Y K, Lee C W. Catal Lett, 2011, 141: 1047

[18] Piegsa A, Korth W, Demir F, Jess A. Catal Lett, 2012, 142: 531

[19] Samoila P, Boutzeloit M, Salem I, Uzio D, Mabilon G, Epron F, Marecot P, Especel C. Appl Catal A, 2012, 415-416: 80

[20] Du H, Fairbridge C, Yang H, Ring Z. Appl Catal A, 2005, 294: 1

[21] Yu Z W, Li S H, Wang Q, Zheng A M, Xu J, Chen L, Deng F. J Phys Chem C, 2011, 115: 22320

[22] Feike M, Demco D E, Graf R, Gottwald J, Hafner S, Spiess H W. J Magn Reson Ser A, 1996, 122: 214

[23] Fyfe C A, Gobbi G C, Klinowski J, Thomas J M, Ramdas S. Nature, 1982, 296: 530

[24] Lippmaa E, Maegi M, Samoson A, Engelhardt G, Grimmer A R. J Am Chem Soc, 1980, 102: 4889

[25] Engelhardt G, Lohse U, Lippmaa E, Tarmak M, Magi M Z. Anorg Allg Chem, 1981, 482: 49

[26] Kotrel S, Knozinger H, Gates B C. Microporous Mesoporous Mater, 2000, 35-36: 11

\section{Graphical Abstract}

Chin. J. Catal., 2013, 34: 2153-2159 doi: 10.1016/S1872-2067(12)60721-9

Synergism between the Lewis and Brönsted acid sites on HZSM-5 zeolites in the conversion of methylcyclohexane

Chenhai Song, Meng Wang, Li Zhao, Nianhua Xue*, Luming Peng, Xuefeng Guo, Weiping Ding*, Weimin Yang, Zaiku Xie Nanjing University; Shanghai Research Institute of Petrochemical Technology

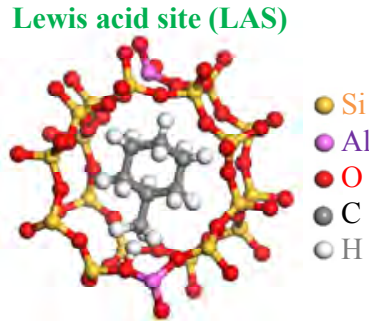

Brönsted acid site (BAS) propene,

Synergistic effect between LAS and BAS

Increased conversion rate

butenes,

$\mathrm{C}_{1}-\mathrm{C}_{4}$ alkanes,

liquid hydrocarbons, aromatics, etc.

A synergistic effect between Lewis and Brönsted acid sites in steamed HZSM-5 zeolites accelerated the conversion and cracking rate of methylcyclohexane conversion. 
[27] Marques J P, Gener I, Lopes J M, Ribeiro F R, Guisnet M. Appl Catal A, 2006, 301: 96

[28] Maier S M, Jentys A, Lercher J A.J Phys Chem C, 2011, 115: 8005

[29] Mihályi R M, Kollár M, Király P, Karoly Z, Mavrodinova V. Appl Catal A, 2012, 417: 76

[30] Zhu N, Wang Y, Cheng D G, Chen F Q, Zhan X L. Appl Catal A, 2009, 362: 26

[31] Kung H H, Williams B A, Babitz S M, Miller J T, Snurr R Q. Catal Today, 1999, 52: 91

[32] Babitz S M, Williams B A, Miller J T, Snurr R Q, Haag W Q, Kung H H. Appl Catal A, 1999, 179: 71

[33] Williams B A, Babitz S M, Miller J T, Snurr R Q, Kung H H. Appl Catal A, 1999, 177: 161

[34] Zholobenko V L, Kustov L M, Kazansky V B, Loeffler E L, Lohse U, Oehlmann G L. Zeolites, 1991, 11: 132

[35] Zholobenko V L, Kustov L M, Kazansky V B, Loeffler E, Lohser U L, Peuker C, Oehlmann G. Zeolites, 1990, 10: 304
[36] Makarova M A, Dwyer J.J Phys Chem, 1993, 97: 6337

[37] Niwa M, Sota S, Katada N. Catal Today, 2012, 185: 17

[38] Makarova M A, Bates S P, Dwyer J. J Am Chem Soc, 1995, 117: 11309

[39] Van Bokhoven J A, Tromp M, Koningsberger D C, Miller J T, Pieterse J A Z, Lercher J A, Williams B A, Kung H H. J Catal, 2001, 202: 129

[40] Marques J D, Gener I, Ayrault P, Bordado J C, Lopes J M, Ramôa Ribeiro F, Guisnet M. Microporous Mesoporous Mater, 2003, 60: 251

[41] Masuda T, Fujikata Y, Mukai S R, Hashimoto K. Appl Catal A, 1998, 172: 73

[42] Wischert R, Laurent P, Copéret C, Delbecq F, Sautet P. J Am Chem Soc, 2012, 134: 14430

[43] Yu Z W, Li S H, Wang Q Zheng A M, Jun X, Chen L, Deng F. J Phys Chem C, 2011, 115: 22320

[44] Li S H, Zheng A M, Su Y C, Zhang H L, Chen L, Yang J, Ye C H, Deng F. JAm Chem Soc, 2007, 129: 11161

\title{
HZSM-5沸石中Lewis酸与Brönsted酸协同作用下的甲基环己烷开环反应
}

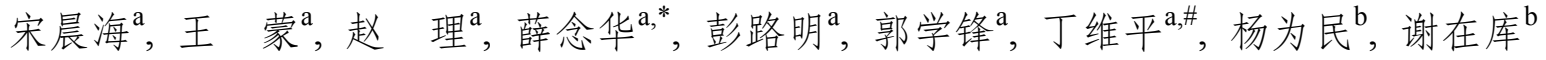 \\ a南京大学化学化工学院介观化学教育部重点实验室, 江苏南京210093 \\ b国石油化工股份有限公司上海石油化工研究院, 上海201208
}

摘要: 由于水蒸气处理HZSM-5生成的骨架外铝在分子笁中体现Lewis酸性, 分子笁中骨架外铝物种的可移动性导致Lewis酸与分 子笁本身的Brönsted酸在空间上具有临近性. 当甲基环己烷分子在HZSM-5的笼中转化时, Lewis酸与Brönsted酸的协同作用加快 了甲基环已烷分子的转化速率, 且骨架外铝物种浓度越高, 这种协同效应越明显. 而产物的选择性只与催化剂的孔道结构有关, 与水蒸气处理所导致的酸性质的变化无关.

关键词: 甲基环己烷; HZSM-5; 水蒸气处理; 协同效应; Lewis酸; Brönsted酸

收稿日期: 2013-09-27. 接受日期: 2013-10-08. 出版日期: 2013-11-20.

*通讯联系人. 电话: (025)83686115; 传真: (025)83317761; 电子信箱: nianhua@nju.edu.cn

\#通讯联系人. 电话: (025)83595077; 传真: (025)83317761; 电子信箱: dingwp@nju.edu.cn

基金来源：国家自然科学基金(21273107，21103087); 中央高校基本科研业务费专项资金(1107020524); 高等学校博士学科点专 项科研基金(20100091120035).

本文的英文电子版由Elsevier出版社在ScienceDirect上出版(http://www.sciencedirect.com/science/journal/18722067). 